\title{
AC 2008-2860: ENERGY ISSUES AND STUDY ABROAD EXPERIENCE IN COSTA
}

RICA

Karim Altaii, James Madison University

Dr. Altaii is a Professor at James Madison University.

Hennia cavallini, University of Costa Rica

Prof. cavallini is the Mechanical Engineering Department Head. 


\title{
Energy Issues and Study Abroad Experience in Costa Rica
}

\begin{abstract}
James Madison University's (JMU's) summer Study Abroad Program in Costa Rica was designed for students from JMU's unique Integrated Science and Technology (ISAT) program to study alongside students from the University of Costa Rica (UCR). This program provided many educational benefits for all involved including understanding the fundamentals of energy, its uses and resources, exposure to international energy technologies, experience and understanding associated with living and working in an international setting; and applied, interdisciplinary course experience that integrates the technical, social, and economic dimensions of an international setting. Seven students from each of the institutions were taught by a team of interuniversity faculty and learned via immersion about Costa Rican culture, history, geography, language and political affairs. Each JMU student was hosted by a Costa Rican family and the course included hands-on field trips to operational renewable energy projects and installations in the region. This paper contains an overview of the technical and cultural topics taught, the logistics involved in preparing for and implementing the program, along with a discussion of the facets of the program that were successful and those which are under developed.
\end{abstract}

\section{Introduction}

In today's global interdependence, international experience for students is becoming more important than ever in higher education. Students need to understand other cultures, to learn other languages, and to share and respect similarities and differences. To this end, international experience, both abroad and on campus, became one of James Madison University's (JMU's) ongoing commitments. Over the past 10 years, the number of study abroad programs at JMU has grown substantially. The Office of International Program ${ }^{1}$ (oIP) at JMU offers over 63 semester and short-term programs in 34 countries.

This paper describes our experiences in creating and implementing a study abroad program in Costa Rica for JMU's ISAT students including preparation before and during the trip, description of the courses taught, trips made, logistics, successes, and planned changes for next year's experience. It is meant as a guide for those educators considering starting a joint study abroad program involving cross-cultural teams of both faculty and students.

\section{Preparation for the Course}

Besides being a paradise on earth, more than $90 \%$ of the electricity generated in Costa Rica comes from renewable energy sources ${ }^{2}$ (hydroelectric, geothermal, and wind); these two factors were the primary drivers in choosing Costa Rica for the program. The director of the program at JMU sought to work with an academic institution in Costa Rica rather than an agency because agencies tend to focus on their potential profits. The initial contact was simply made by a telephone call to the director of the mechanical engineering department at the University of Costa Rica (UCR) in May 2006 by JMU Professor Karim Altaii. Subsequently, Professor Altaii traveled to Costa Rica for 4 days to investigate the possibility of a joint course and the requisite 
logistics for implementing such a program. The trip's itinerary included the identification of space for the courses, requisite labs at UCR, and identification of the experimental facilities that could be provided by UCR that fit the needs of JMU's Integrated Science and Technology energy class (ISAT 212). Also, potential UCR energy and cultural instructors and the requisite supporting technicians were identified. It was agreed that the course would be offered from July 6 to August 9, 2007, an intersession period at both JMU and UCR. Immediately after returning to the U.S., Professor Altaii commenced the recruitment of students to participate in the program at JMU. The recruiting efforts involved presenting overviews of the proposed program in ongoing classes and at an international fair held at JMU, mass e-mailing to students, pamphlets and posters, along with a display on a hallway TV monitor. Seven students signed up for the incipient program from JMU and, in parallel, Professor Altaii's counterpart_Professor Hennia Cavallini, recruited seven students to participate at UCR. The two professors agreed that ideally the number of students from each university should be the same for pairing on labwork, homework, presentations, etc. Once the student groups had been identified, they had bi-weekly preparation meetings that focused on acquiring the necessary passports, airplane tickets, immunizations, insurance, an overview of the items to be packed, the types of clothing that would be needed, and the group concurred on a list of out-of-class activities that they wanted to pursue and participate in. Student input was highly appreciated by the organizing faculty and students were included throughout the trip-planning process.

Once activities had been identified, arrangements were made by Professor Cavallini to check on prices and the availability of hotels, transportation, etc. as the costs of these items were needed for developing the program budget.

Each JMU student completed a housing application form which was prepared by the UCR International office. The application form included expected norms between the host families and the JMU students and a family questionnaire including preferences in regards to pets, smoking, gender, age, number of people living with the family, location, personal interests, etc.

From January through July of 2007, there was a tremendous amount of information exchanged between the two universities concerning course logistics including over 70 e-mails and 30 telephone calls. A course website ${ }^{3}$ was created at JMU to add the necessary course and trip information and all of the involved students (both JMU and UCR) were required to post a photograph and a short biography of themselves as a means of virtual introduction. A program logo was made by the UCR Media Center and was used on T-shirts, binders, and pamphlets to promote the program.

\section{Budget Preparation}

For this experience, the budget included items such as faculty, teaching assistant, and administrative support (JMU and UCR) salaries, guest lecturers and guides, admission tickets, tours, books, office supplies (paper, notebooks, DVDs ), printing and copying, housing for JMU students and faculty, hotels, food and refreshments, social activities, lab equipment and supplies, airport taxes, directors' airfare tickets, long distance phone calls and ground transportation expenses. 


\section{Arrival in Costa Rica}

The participating faculty, teaching assistant, and the seven students from JMU, were greeted at the airport in Costa Rica by the participating UCR faculty and students. Upon the group's arrival at UCR, an orientation session was led by the UCR faculty during which the students introduced themselves to the group. Each group member (faculty, staff and students) was given a program T-shirt and a folder that contained information about Costa Rica, a list of "dos and don'ts", a map of San Jose, addresses of all host families, and the telephone number of everyone in the group. Host families were present at this orientation and were introduced to the student whom they were hosting; each JMU student departed the meeting with his/her host family.

\section{Housing and Ground Transportation}

Each JMU student was housed by a Costa Rican family according to his/her preferences delineated in the housing application form. Host families were responsible for lodging and two meals (breakfast and dinner) during the week and for three meals during the weekends when the students were in town. Students were given instructions on using public transportation from and to their host families and to and from the UCR campus. Meals and transportation outside of this arrangement were the responsibility of the participating students. Field trip transportation was provided by UCR.

\section{Course Offerings}

Two courses were offered:

1. ISAT 212- Energy Issues in Science and Technology (3 Credits)

2. GEOG 450- Contemporary Costa Rica (3 Credits) including one hour per day of Spanish language study.

A typical weekday schedule (Monday through Thursday) for a participating JMU student was as follows:

\begin{tabular}{|l|l|}
\hline 9:30- 10:30 am & ISAT 212 Lecture \\
\hline 10:30- 10:40 am & Break with Refreshments \\
\hline 10:40 - 11:400 am & ISAT 212 Lecture \\
\hline 11:40 am- 1:00 pm & Lunch (UCR Cafeteria_-Prepaid by the Program) \\
\hline 1:00-2 pm & Spanish Language Class \\
\hline 2:00-4:00 pm & GEOG 450 Lecture and/or Short Field Trip \\
\hline 4:00- 6:00 pm & Study/Homework Preparation for the Following Day \\
\hline 6:00 pm & Depart to Host Family \\
\hline
\end{tabular}

Fridays mornings were devoted to ISAT 212 laboratories which included experiments such as calorimetry, solar collectors and photovoltaic cells. Weekend field visits to power plants such as thermal and renewable, started early on Friday afternoons and emphasized energy conversion technologies. 


\section{Description of Courses}

\section{ISAT 212 - Energy Issues in Science and Technology}

This is a required course for all ISAT students. The pre-requisite for the course is ISAT 152 Analytical Methods II (Topics in Applied Physics) and also requires good academic standing (i.e. a minimum grade point average of 3.0).

The objective of this course is to introduce important issues and scientific concepts relevant to the use of energy in modern society. The purposes of this course are to (a) introduce students to the broad field of energy and its importance in modern technological society; (b) develop a basic understanding of important scientific concepts in preparation for upper-level energy courses; and (c) develop an appreciation of the environmental and economic issues associated with the different energy technologies and the challenges of sustainable energy development.

The course is divided into five modules. In the first module, basic concepts regarding thermal energy and energy effects associated with changes in temperature and the physical state of matter were covered. The objective of the second module is to examine the phenomenon of electromagnetic radiation within the context of solar energy. The characteristics of solar radiation and its interactions with various materials is considered. The third module involves the combustion of fossil fuels, an important source of chemical energy. Related topics include stoichiometric calculations to predict the amount of heat released from oxidation-type chemical reactions and energy conversion. The fourth module examines electrical energy, and the generation, transmission, and distribution of electrical power. Fundamental concepts related to electricity production, transmission and distribution are considered. The fifth and final module covers the properties and structure of the atomic nucleus. Related concepts include half-life, nuclear radiation, reactions, and energy conversion.

It was the objective of the instructors of ISAT 212 for this course to provide a solid foundation for upper-level studies in energy. Analytical tools such as the $1^{\text {st }}$ law of thermodynamics are developed and applied in ISAT 212 to provide students with an understanding of physical concepts and technologies associated with energy and for them to solve related problems. Future courses will expand upon the breadth and depth of this course. Information relevant to the course including policies, schedules, and the syllabus were posted on Blackboard (BB) and students were required to visit this site regularly.

Each class met four times per week for lecture and recitation activity (M/T/W/Th) from 9:30 a.m. to 12:00 noon and once each week, on Fridays, for a laboratory activity (see Table 1 for the weekly schedule). New material was generally introduced in the lectures and short quizzes were given regularly to assess student understanding of the material covered. 
Table 1 ISAT 212 Issues in Science and Technology Syllabus

\begin{tabular}{|c|c|c|c|c|}
\hline Week & Dates & Topics & Reading Assignment & $\begin{array}{c}\text { Laboratory/ } \\
\text { Recitation/Miscellaneous }\end{array}$ \\
\hline & Module I & Energy Issues and Concepts & $\begin{array}{l}\text { S: Serway 6th Ed. } \\
\text { H: Hinrichs 4th Ed. }\end{array}$ & \multirow{6}{*}{$\begin{array}{c}\text { Meet in the Heat Transfer } \\
\text { Lab } \\
\text { Lab } 1 \text { (UCR) } \\
\text { Heat Transfer and R-Factors } \\
\text { Lab } 2 \text { (JMU) } \\
\text { Calorimetry }\end{array}$} \\
\hline 1 & July 9 & $\begin{array}{l}\text { Course introduction; Energy } \\
\text { issues and concepts }\end{array}$ & $\mathrm{H} / 1-29,87-92$ & \\
\hline 2 & July 10 & $\begin{array}{l}\text { Conservation of energy; } \\
\text { Temperature; Ideal gas model }\end{array}$ & $\begin{array}{l}\text { S/ 580-595; 605-607 } \\
\mathrm{H} / 33-57\end{array}$ & \\
\hline 3 & July 11 & $\begin{array}{l}\text { Heat transfer by conduction, } \\
\text { convection, radiation }\end{array}$ & $\begin{array}{l}\mathrm{S} / 623-631 \\
\mathrm{H} / 106-114,130-148\end{array}$ & \\
\hline \multirow[t]{3}{*}{4} & July 12 & $\begin{array}{l}\text { Heat; Thermal storage; Specific } \\
\text { heat, Latent heats }\end{array}$ & S/ 607-615 & \\
\hline & $\begin{array}{l}\text { Friday July } 13 \\
\left(1^{\text {st }} \text { Exam }\right)\end{array}$ & & & \\
\hline & Module II & Solar Energy & & \multirow{4}{*}{$\begin{array}{c}\text { Lab } 3 \text { (UCR) } \\
\text { Solar Collector and } \\
\text { Efficiency } \\
\text { Lab } 4 \text { (JMU) } \\
\text { Photovoltaic Cells }\end{array}$} \\
\hline 5 & July 16 & $\begin{array}{l}\text { Combined heat transfer; Solar } \\
\text { radiation }\end{array}$ & $\mathrm{H} / 160-176$ & \\
\hline 6 & July 17 & $\begin{array}{l}\text { Solar-thermal heating and } \\
\text { cooling; Solar-thermal } \\
\text { collectors, systems, } \\
\text { applications }\end{array}$ & $\begin{array}{l}\text { H/ 176-196, pages } \\
\text { from DOE eere } \text { web } \\
\text { site }^{b}\end{array}$ & \\
\hline \multirow[t]{2}{*}{7} & July 18 & $\begin{array}{l}\text { Photovoltaic cells; Solar- } \\
\text { electric collectors and } \\
\text { applications }\end{array}$ & $\begin{array}{l}\text { H/ 387-400, pages } \\
\text { from } \boldsymbol{D O E} \text { eere } \text { web } \\
\text { site }\end{array}$ & \\
\hline & Module III & Energy from Fossil Fuels & & \\
\hline 8 & July 19 & Energy from fossil fuels & $\begin{array}{l}\mathrm{H} / 205-239,75-93 \\
223-231,241-243\end{array}$ & \\
\hline 9 & July 23 & Combustion & $\begin{array}{l}\mathrm{H} / 205-239,75-93 \\
223-231,241-243\end{array}$ & \multirow{5}{*}{$\begin{array}{c}\text { Lab } 5 \text { (UCR) } \\
\text { Bomb Calorimetry }\end{array}$} \\
\hline 10 & July 24 & First law of thermodynamics & $\begin{array}{l}\text { S/ 615-623; } \\
\text { H/ 97-105 }\end{array}$ & \\
\hline \multirow[t]{2}{*}{11} & July 25 & Heat engines and Carnot cycle & $\begin{array}{l}\text { S/ 667-685; } \\
\text { H/ 115-125, 149-155 }\end{array}$ & \\
\hline & Module IV & Electrical Energy and Power & & \\
\hline 12 & $\begin{array}{l}\text { July } 26 \\
\left(2^{\text {nd }} \text { Exam }\right)\end{array}$ & $\begin{array}{l}\text { Electrical energy and power } \\
\text { generation }\end{array}$ & $\begin{array}{l}\text { S/ 795-801, 804-807, } \\
845-849^{\text {a }} \text {; } \\
\text { H/ 317-322, 336-337 }\end{array}$ & \\
\hline 13 & July 30 & Power in a circuit & $\begin{array}{l}\text { S/ 858-869, 1034- } \\
1052 ; \\
\text { H/ 337-339 }\end{array}$ & \multirow{4}{*}{$\begin{array}{c}\text { Lab } 6 \text { (UCR) } \\
\text { AC Circuits \& Oscilloscope } \\
\text { Lab } 7 \text { (UCR) } \\
\text { Transformers }\end{array}$} \\
\hline 14 & July 31 & $\begin{array}{l}\text { Transmission and distribution } \\
\text { of electrical energy and power. } \\
\text { Start of Nuclear Energy }\end{array}$ & $\begin{array}{l}\text { S/ 982-986, 1052-1058; } \\
\text { H/ 340-349, 358-376 } \\
\text { S/ 1448-1471; } \\
\text { H/ 426-447 }\end{array}$ & \\
\hline & Module V & Nuclear Energy & & \\
\hline 15 & August 1 & $\begin{array}{l}\text { Nuclear properties and } \\
\text { reactions Fission and fusion }\end{array}$ & $\begin{array}{l}\mathrm{S} / 1480-1495 \\
\mathrm{H} / 451-456^{\mathrm{a}}\end{array}$ & \\
\hline 16 & August 2 & Final Exam & & \\
\hline
\end{tabular}


There were seven laboratory experiments that focused on topics that were consistent with the course content. The themes of the laboratory experiments were as follows:

1. Residential Energy Conservation: Heat Transfer; Insulation; R-factor

2. Calorimetry: Specific Heat; Latent Heat of Vaporization

3. Solar Collectors: Renewable Power Production; System Efficiency

4. Photovoltaic Cells: Solar Cell I-V Curve; Maximum Power Output from a PV Cell

5. Bomb Calorimeter: Heat Released from a Particular Material

6. Electric Power (1): AC Circuits

7. Electric Power (2): Transformers

Each laboratory handout was posted on the course's web-accessible Blackboard page prior to the lecture on Monday of the week during which the lab was scheduled. Handouts which described the objectives, procedures, and deliverables associated with the laboratory experiment were also given at the beginning of the laboratory. Each handout also included technical writing guidelines associated with a specific component of a formal laboratory report and included a list of deliverables to be completed and turned in for grading (for each lab experiment) including combinations of a data worksheet, graphs, and a partial or complete lab report.

\section{Text and Materials}

Two texts were used in this course, one by Hinrichs and Kleinbach ${ }^{4}$ and the other by Serway and Jewett ${ }^{5}$. Each JMU student had a copy with him/her and shared them with a UCR student. In addition to the textbooks, excerpts and handouts which supplemented the texts were provided by the instructors on an as-needed basis.

ISAT 212, when offered at JMU, includes 7 laboratory sessions of which four of the lab sessions at UCR were identified to be exact replicas, or very similar to, the ones assigned at JMU. One of the JMU labs was replaced by a superior UCR lab, and the lab equipment and requisite supplies for two labs were purchased in the US, used at UCR, and left for future classes at UCR. JMU faculty members generally teamed with UCR faculty for each of the ISAT 212 lectures with all of the lectures being conducted in English.

Three of the labs were conducted in English (both handouts and verbal instruction), and four were conducted in Spanish providing for language practice for both JMU and UCR students. Each student from JMU teamed with a UCR student in conducting each experiment and its associated laboratory write-up. After the first lab session, JMU students complained that they did not understand much of the material due to the language barrier, but the apparent barrier turned out to be a motivator which compelled the students to concentrate more during future lab sessions because the instruction was being given in a less familiar language. During the last lab 
session, JMU students were asked to translate, on-the-spot, the entire lab from Spanish to English; the result was amazing as every student was then able to successfully translate the entire lab write-up.

To facilitate learning, all of the students were given a complete hardcopy of the lecture PowerPoint presentations in a 3-ring binder at the beginning of the program. Homework assignments and the solutions were posted on Blackboard at appropriate times and lab modules were posted on Blackboard prior to each lab session, and a hard copy of each lab module was distributed at the beginning of each lab.

\section{GEOG 450 - Contemporary Costa Rica}

The Contemporary Costa Rica class included topics such as geography (provinces, topography, etc), government (form of government, Costa Rican elections, etc), Costa Rican people (ethnic groups, traditions, stereotypes, and class divisions), typical dishes, history (important events, independence, battles, etc), popular dances, immigration, religion, and economy (tourism, agriculture, trade agreements, etc.). The class also included Spanish language training for one hour per day and the class was taught by an instructor from UCR.

An interesting development occurred during the first week of the class wherein both the JMU students and UCR students felt that they were not learning from the instructor (style and method) and the UCR students felt that the instructor was not presenting an honest overview of Costa Rica. With student input, it was decided that the remainder of the course would be taught by UCR students with JMU students learning directly from discussions with UCR students. The JMU students overwhelmingly — based on the class evaluations - reflected that this approach was much more effective than traditional instruction.

A detailed syllabus, including the activities performed in this course, is presented in Table 2. Hard copy of all course material was distributed at the beginning of each lecture.

A newly opened computer lab, with internet access, was made available to all participating students throughout the program's duration. 
Table 2 GEOG 450 Cultural Course Syllabus and Activities

\begin{tabular}{|c|c|c|c|c|}
\hline July 9th & July 10th & July 11th & July 12th & July 13th \\
\hline Geography & Government & Social Behavior & Costa Rican People & History \\
\hline \multirow[t]{5}{*}{ Provinces } & Form of government & Distance & Stereotypes & National Museum \\
\hline & Costa Rican elections & Slang & General characteristics: & \\
\hline & Power division & Consumerism & Hora Tica & \\
\hline & Costa Ricans' point of view & Use of cell phones & Pasividad & \\
\hline & Main problems & & Choteo & \\
\hline July 16th & July 17th & July 18th & July 19th & July 20th \\
\hline History & History & Popular dances & Social conditions & Religion \\
\hline Important events & Santa Rosa's Battle & Salsa & Class division & Catholic \\
\hline Independence Day & Civil War 1948 & Merengue & Immigration & Evangelical \\
\hline \multirow[t]{2}{*}{ Rivas Battle } & Anexation of Nicoya & & & \\
\hline & & $* * *$ Guests & & *Basilica de los Angeles Church \\
\hline July 23rd & July 24th & July 25th & July 26th & July 27th \\
\hline Economy & Economy & Traditions & Traditions & Traditions \\
\hline Tourism & TLC & Guanacaste & Saint Valentine's Day & Turnos: Town Fairs \\
\hline \multirow[t]{4}{*}{ Movie } & Agricultural products & Traditional dance & Mother's Day & Guanacaste \\
\hline & Butterflies & & Father's Day & Easter Week \\
\hline & & & Children's Day & Independence Day \\
\hline & & & Virgin of Los Angeles Day & Limon's Carnival \\
\hline July 30th & July 31st & August 1st & August 2nd & August 3rd \\
\hline Typical dishes & Traditions & Traditions & Arts & Party \\
\hline Description & Less famous traditions: & Christmas and New Year & Faculty of Arts (UCR) & \\
\hline \multirow[t]{3}{*}{ *** Restaurant La Casita } & La yeguita & Lights Festival & & \\
\hline & Corn fair & Zapote and Palmares & & \\
\hline & Funerals in Limón & SJ Carnival and Horse parade & & \\
\hline
\end{tabular}




\section{Tours}

There were tours with focus on topics consistent with the content of the courses. Short trips included town fairs and carnivals, two churches, historical sites, museums and traditional restaurants. Weekend trips combined touristic activities and power plants tours. The tourist activities included water falls, volcanoes, beaches, cities, a rainforest and Zip line.

Power Plant Tours: All power plant tours were coordinated between UCR faculty and the Instituto Costarricense de Electricidad (ICE) ${ }^{6}$. Tours included a visit to the following four power plants: Arenal $157 \mathrm{MW}$ hydroelectric power plant, Limon $245 \mathrm{MW}$ fossil fuel power plant, Miravalles $165 \mathrm{MW}$ geothermal power plants, and Tilaran $30 \mathrm{MW}$ wind turbine farm. Table 3 lists the plant name, type, capacity, number of units in each power plant and the year constructed. For tour locations and itinerary, please refer to Figure 1.

Table 3 Power Plants Locations, Type, Capacity, Number of Units and Year Constructed.

\begin{tabular}{|c|c|c|c|c|c|}
\hline Plant Name & Location & Type & $\begin{array}{c}\text { Generation } \\
\text { Capacity } \\
\text { (MW) }\end{array}$ & $\begin{array}{c}\text { Number } \\
\text { of Units }\end{array}$ & $\begin{array}{c}\text { Year } \\
\text { Constructed }\end{array}$ \\
\hline $\begin{array}{c}\text { Arenal (Planta } \\
\text { Hidraulica) }\end{array}$ & Arenal & Hydroelectric & 157 & 3 & 1982 \\
\hline $\begin{array}{c}\text { Moín I, } \\
\text { Moín II, } \\
\text { Moín III }\end{array}$ & $\begin{array}{c}\text { Moin } \\
\text { (Limon) }\end{array}$ & $\begin{array}{c}\text { Thermal, Diesel, and } \\
\text { Bunker }\end{array}$ & 245 & 10 & 1977, \\
\hline $\begin{array}{c}\text { Miravalles I, } \\
\text { Miravalles II, } \\
\text { Miravalles III, } \\
\text { Miravalles V }\end{array}$ & Miravalles & Geothermal & 165 & 5 & $1990-1995$, \\
\hline $\begin{array}{c}\text { Aeroenergía } \\
\text { S.A, MOVASA }\end{array}$ & Tilaran & & & & 2003 \\
\hline
\end{tabular}




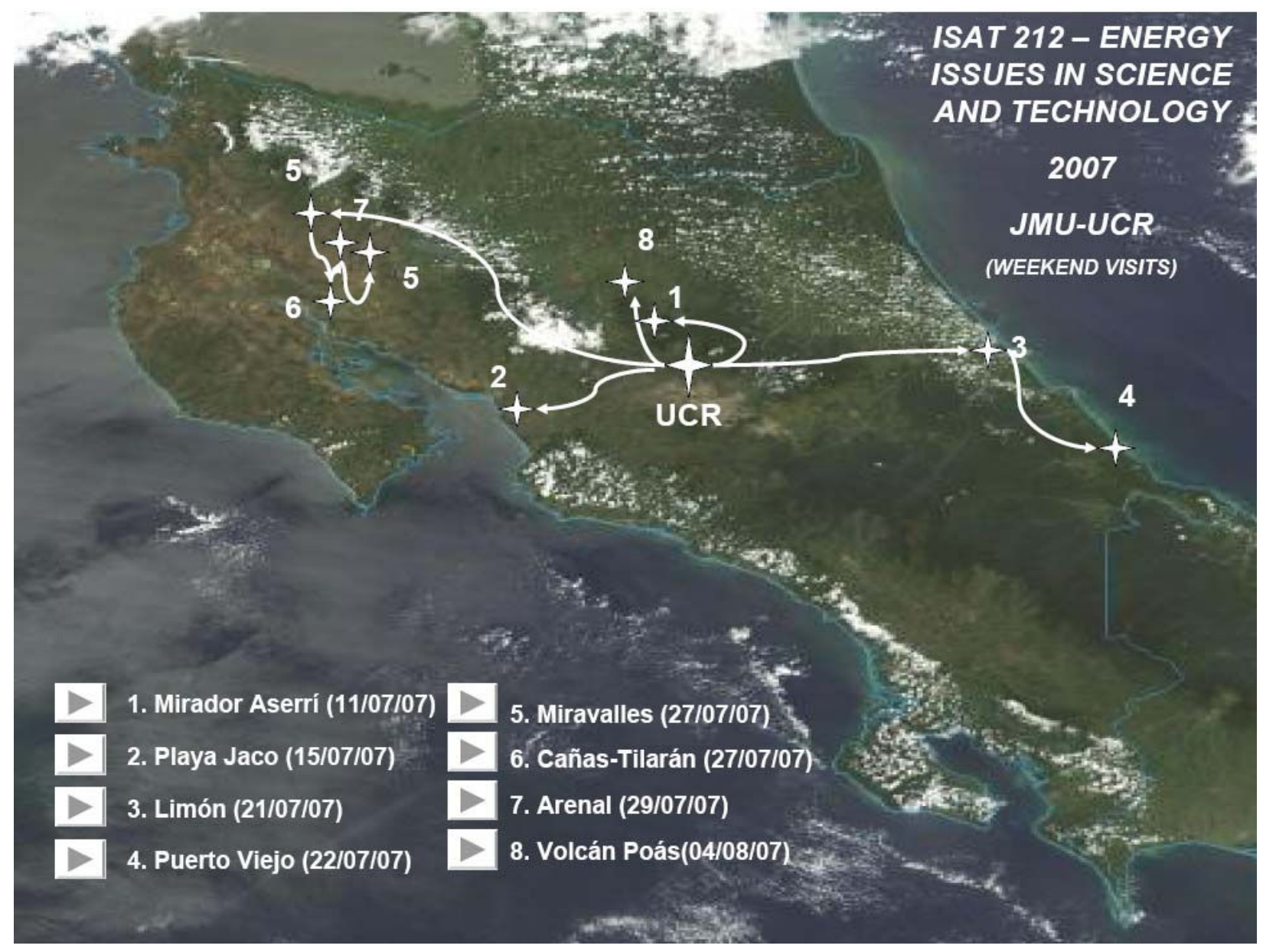

Figure 1 Locations of Weekend Trips in Costa Rica.

For both classes, students were encouraged to offer comments and suggestions throughout the semester. Students' feedback was also provided in the form of a daily journal, end-of-course faculty and course evaluations, housing evaluations, and a web-based course evaluation conducted by OIP after the JMU students returned to the U.S. A housing evaluation form included feedback about location, safety, ease of transportation, comfort, food, cleanliness, etc. Except for one incidence of an assigned family not working out, which was rectified during the first week of the program through reassignment, all of the participating JMU students were pleased and content with their assigned families. Additionally, evaluation forms were completed by JMU students to provide feedback about their experience with the host families. Judging from students' housing evaluation forms, in general, host families were very hospitable and generous with their time, trying their best to accommodate students and make them feel at home.

Photos and short videos were taken by many of those involved in the program were compiled on a professionally developed DVD which each participant received and two wall size posters of the experience were made for future recruiting. During the last day of the program, a BBQ party was given by UCR students during which they played Frisbee, soccer, and students and faculty said their goodbyes and thanks and exchanged gifts. 


\section{Students' Comments}

Below are comments taken from participant students' journals:

\section{JMU students}

- Experience of a life time, anyone who has not taken 212 and is planning on taking a Maymester for it, please consider this as a strong alternative.

- The past month has been great. Great bonding with UCR students. Both the lab and the course included topics that interested me very much and are quite useful for my career. Also, both were excellent experiences that allowed me to get in touch with different teaching methods. Besides they complimented each other making the understanding of the subject a little easier. The homework was an awesome exercise on the subject seen everyday

- We headed up into the mountains to a restaurant called Ram Luna, it overlooked all of the city lights of the central valley. The view was gorgeous and the food was great too.

- I really enjoyed the live music and traditional dancing. I felt that today was the best way to enjoy the culture yet. The labs were both in English and Spanish and encouraged team work. Got a lot of hands-on experience being in Costa Rica where we could visit power plants every weekend and study their use of alternative sources of energy.

- We headed to the Hydro and wind plant which were personally my favorite 2 activities (212 related). Seeing the power of hydro and the drive shaft spinning was incredible.

- Guanacaste is an extremely beautiful region; the drive to Arenal was the most incredible drive/experience I have ever had. I felt like I was in Jurassic park. We got so lucky to see the volcano at sunset and to top it off we saw a double rainbow over the entire volcano.

- The course has been good, I have learned a lot and made a lot of new friends, the best part is experiencing the bond with UCR students and having them show us the way they do things. I cannot wait until some of them come to JMU so we can show them our way

\section{UCR students}

- I just want to thank you for the great experience, the 212 has been to me.

- I've learned so much, and had a lifetime experience with the guys. Thank you.

- Another thing, which I wasn't used to, it is the huge number of homework we have, with this rate we can keep practicing what we've learned, day by day. I like that fact that we have to do homework to learn, not just to have a grade.

- Our group looks well integrated, and there is always a cultural learning when commenting any subject in the class. 
- Thank for all the work you've put into the trip- its been a wonderful work hard play hard experience.

- It was a great month, really hard work, not much time but it was fun. I will miss all my classmates' .Hope to have classes with them again.

- The course was really cool, the instructor was an excellent teacher, explained really clearly. The people (my classmates) were awesome persons.

- I got so used to seeing them every single day for a month that I'm really going to miss them when they are gone. The trips were really cool also I've learned a lot in the power plants and had a lot of fun with all of my new friends.

- Everything was great, for being the first time they've done this.

\section{Program Successes and Future Adjustments}

Overall, the program turned out to be a great experience for all involved. Everyone was eager to cooperate to make the program successful and the working relationship between faculty, staff and students was excellent. Students (UCR and JMU) behaved well, took the classes seriously, and there was a great deal of respect and bonding between the two student groups. Generally, the program was executed as planed with minor adjustments implemented as needed.

Next year's adjustments will include extending the program to six weeks to lessen the daily workload and intensity of the courses and to provide more free time for students to venture out and learn about Costa Rica on their own. Two of the laboratory experiments are being rewritten and improved and UCR students will be assigned the task of teaching the JMU students Spanish. Another adjustment will be that UCR students will house JMU students in their homes and a joint trip to the Panama Canal may be included.

\section{Concluding Remarks}

Seven JMU students along with seven students from the UCR learned about energy issues through participation in an innovative study abroad program offered through JMU's ISAT program in conjunction with UCR. There were many benefits to the participating students including understanding the fundamentals of energy, its uses and resources, exposure to international energy technologies, experience and understanding associated with living and working in an international setting; and an applied, interdisciplinary course experience that integrated the technical, social, and economic dimensions of an international setting. Classes were taught by faculty teams from JMU and UCR and the students were immersed in Costa Rican culture, history, geography, language and political affairs. The JMU students were hosted by Costa Rican families and course experiences included visits to renewable energy projects and installations. In summary, it was an exceptional educational experience for everyone involved and the faculty team is planning to offer the experience again in 2008. 


\section{Acknowledgments}

The authors would like to thank the Office of International Programs at James Madison University, especially Dr. Lee Sternberger and Ms. Jackie Ciccone, along with Dra. Yamileth Gonzalez, Dra. Libia Herrero and Dra. Ana Sittenfeld at the University of Costa Rica for their invaluable guidance and support.

\section{Bibliography}

1. http://www.jmu.edu/international/

2. www.iea.org/Textbase/stats/PDF_graphs/CRELEC.pdf

3. http://www.isat.jmu.edu/costarica/links.html

4. Hinrichs and M. Kleinbach, "Energy: Its Use and the Environment," $4^{\text {th }}$ Edition, Thomson/ Brooks/ Cole College Publishers, 2006.

5. R. A. Serway and J. W. Jewett, Jr., "Physics for Scientists and Engineers," $6^{\text {th }}$ Edition, College Publishers, 2004

6. https://www.grupoice.com/saceventanilla/index.htm 